\title{
Magnesian calcite synthesis from calcium bicarbonate solution containing magnesium ions in the presence of fluoride and phosphate ions
}

\author{
TAmotsu OOMORI ${ }^{1}$, Atsuko Kyan ${ }^{1}$ and Yasushi Kitano ${ }^{2}$ \\ Department of Chemistry, College of Science, University of the Ryukyus, \\ Nishihara, Okinawa 903-01 ${ }^{1}$, and \\ School of Human Sciences, Sugiyama-Jogakuen University, Nissin-cho, Aichi-gun, \\ Aichi Prefecture 470-01², Japan
}

(Received September 21, 1988; Accepted February 20, 1989)

\begin{abstract}
Magnesian calcites were precipitated from $10 \mathrm{mM} \mathrm{Ca}\left(\mathrm{HCO}_{3}\right)_{2}\left(\mathrm{Ca}^{2+}, 400 \mathrm{mg} / \mathrm{l}\right)$ solutions containing 35 or $53.5 \mathrm{mM} \mathrm{Mg}$ ions $\left(\mathrm{Mg}^{2+}, 850\right.$ or $\left.1300 \mathrm{mg} / \mathrm{l}\right)$ in the presence of fluoride and phosphate ions in various concentrations. Magnesian calcite formation from aqueous solution was favored by the presence of fluoride ions $(0.5$ to $2.5 \mathrm{mM})$ or phosphate ions $(0.025$ to $0.5 \mathrm{mM})$ in a parent solution. Aragonite and/or monohydrocalcite are formed below or above the critical concentrations of these ions. The presence of phosphate or fluoride ions in a solution inhibits adsorption of $\mathrm{Mg}^{2+}$ ions on calcite surface, which may cause the magnesian calcite formation.
\end{abstract}

\section{INTRODUCTION}

Occurrence and persistance of $\mathrm{Mg}$-bearing carbonates such as magnesian calcite and protodolomite in sedimentary environments are one of the most interesting problems in the field of carbonate geochemistry. To solve this problem, it is required to elucidate the controlling factors of the polymorphic crystallization from aqueous solution and the $\mathrm{Mg}$ content of calcium carbonate.

Kitano and coworkers and the several authors have studied the polymorphic crystallization of calcium carbonate in the presence of various cations and anions: Presence of $\mathrm{Mg}^{2+}$ and other divalent cations with smaller ionic radius than that of calcium in solution favor aragonite formation, whereas these metal carbonates are calcitic in crystal structure and easily incorporated into calcite as solid-solution (Kitano, 1962; Kitano and Hood, 1962; Kitano et al., 1969; Berner, 1975; Oomori and Kitano, 1985; Oomori et al., 1987). On the other hand, presence of divalent cations with larger ionic radius than that of calcium in solution favors calcite formation, whereas those metal carbonates are aragonitic in structure and easily incorporated into aragonite (Kitano et al., 1971). Similarly, anions such as $\mathrm{F}^{-}$, phosphate, $\mathrm{Cl}^{-}$, dissolved silica and borate ions in solution favor calcite formation, and these ions are easily incorporated into aragonite (Kitano and Okumura, 1973; Kitano et al., 1975, 1978, 1979b; 1979c).

In marine environments, both $\mathrm{Mg}^{2+}$ ions, promoter ions for aragonite formation, and $\mathrm{F}^{-}$ and phosphate ions, promoter ions for calcite formation, are coexistent. Studies on calcium carbonate crystallization from solution in the presence of these ions are of particular interest for considering the occurrence of $\mathrm{Mg}$-bearing carbonates in nature. The purpose of this paper is to present evidence that the dissolved phosphate and fluoride ions in solution strongly affects the polymorphic crystallization of $\mathrm{CaCO}_{3}$ and the incorporation of $\mathrm{Mg}^{2+}$ ions from $\mathrm{Ca}\left(\mathrm{HCO}_{3}\right)_{2}$ solution. 


\section{Experimental Procedures}

(a) Calcium carbonate synthesis

Calcium carbonate was synthesized in the following procedures as described by Kitano (1962): $\mathrm{Ca}\left(\mathrm{HCO}_{3}\right)_{2}$ solution was prepared by bubbling $\mathrm{CO}_{2}$ gas $\left(p_{\mathrm{CO}_{2}}=1 \mathrm{~atm}\right)$ into a suspension of reagent grade $\mathrm{CaCO}_{3}$ (Kanto Chem. Co.), and then by filtering through Toyo filter paper (no. 5c). This $\mathrm{Ca}\left(\mathrm{HCO}_{3}\right)_{2}$ solution contains about 10 $\mathrm{mM}$ of $\mathrm{Ca}^{2+}$ ions. Parent solutions were prepared by adding $\mathrm{MgCl}_{2}$ solution and $\mathrm{KF}$ solution, $\mathrm{KH}_{2} \mathrm{PO}_{4}$ solution or ATP solution (adenosine triphosphate disodium salt trihydrate) into the $\mathrm{Ca}\left(\mathrm{HCO}_{3}\right)_{2}$ solution before precipitation started.

The $1000 \mathrm{ml}$ of the parent solutions dissolving 35 or $53.5 \mathrm{mM} \mathrm{Mg}^{2+}$ and $\mathrm{F}^{-}(0$ to $4 \mathrm{mM})$, phosphate ( 0 to $1.5 \mathrm{mM}$ ) or ATP ( 0 to $0.37 \mathrm{mM}$ ) were taken in glass vessels and maintained at $25^{\circ} \mathrm{C}$ with occational stirring for about 5 weeks. With the lapse of time, carbon dioxide gas escaped to the air and calcium carbonate was formed from the solutions. It took a couple of days to make calcium carbonate begin to precipitate. Phosphate and fluoride ions were coprecipitated with calcium carbonate during the course of precipitation. After several weeks, more than $70 \%$ of dissolved calcium were precipitated. The precipitates were filtered off through Millipore filter $(0.45 \mu \mathrm{m})$ and washed with distilled water.

The initial and final concentrations of $\mathrm{Mg}^{2+}$ and $\mathrm{Ca}^{2+}$ ions in a parent solution were determined by EDTA titration. The calcium ion concentration varies from about 350 to $50 \mathrm{mg} / 1$ during the course of experiments. Phosphate-P in the parent solutions and carbonate precipitates were determined by colorimetry (Murphy and Riley, 1962). The calcium and Mg contents and mineral composition of the precipitates were determined by atomic absorption (Hitachi 170-50A type) and X-ray diffractometry (Rigakudenki; $35 \mathrm{kV}, 15 \mathrm{~mA}$ ), respectively.

(b) Adsorption of $\mathrm{Mg}^{2+}$ ions

Adsorption of $\mathrm{Mg}^{2+}$ ions on calcite surface in the presence of fluoride or phosphate ions was ex- amined in the following way; Reagent grade calcite powder (Kanto Chem. Co.) was suspended in $50 \mathrm{ml}$ of $0.107 \mathrm{mM} \mathrm{MgCl}$, solution $\left(\mathrm{Mg}^{2+}\right.$ : $2.6 \mathrm{mg} / \mathrm{l})$ containing fluoride ions (0 to $10 \mathrm{mM}$ ) or phosphate ions ( 0 to $2 \mathrm{mM})$ at $20^{\circ} \mathrm{C}$. The solutions were stirred for about one hour and filtered through Toyo filter paper (No. 5C). The initial and final concentrations of $\mathrm{Mg}^{2+}$ ions of the solution were determined by atomic absorption.

\section{Results AND Discussion}

Effect of fluoride ions in parent solution on crystal form and $\mathrm{Mg}$ content of carbonate
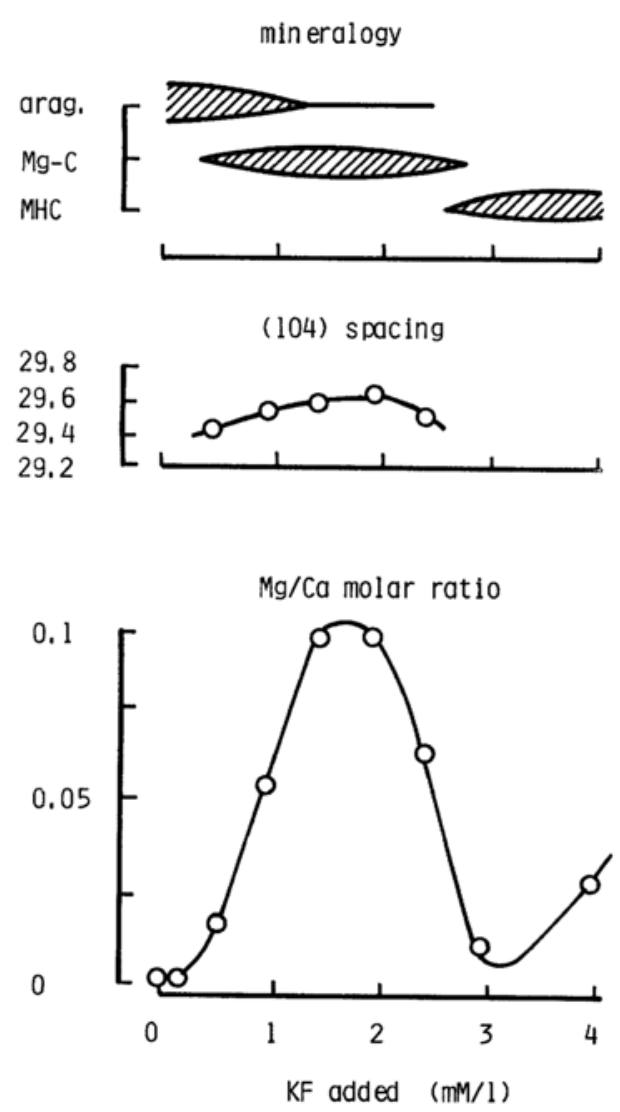

Fig. 1. Effect of fluoride ion concentration on mineral composition of precipiates, diffraction angle (20) of (104) spacing of calcitic carbonates and $\mathrm{Mg} / \mathrm{Ca}$ molar ratio in the precipitates. Carbonates were precipitated from the $10 \mathrm{mM} \mathrm{Ca}\left(\mathrm{HCO}_{3}\right)_{2}$ solution $\left(\mathrm{Ca}^{2+}, 400 \mathrm{mg} / \mathrm{l}\right)$ containing magnesium ions (1300 $\mathrm{mg} / \mathrm{l}$ ) and fluoride ions (0 to $4 \mathrm{mM}$ ). 


\section{precipitate}

The experimental results are shown in Fig. 1. It is seen that fluoride ion concentration in the parent $\mathrm{Ca}\left(\mathrm{HCO}_{3}\right)_{2}$ solution containing $\mathrm{Mg}^{2+}$ ions $(1300 \mathrm{mg} / \mathrm{l})$ shows a large effect on the mineral composition and the $\mathrm{Mg}$ content of carbonate precipitates. Pure aragonite (arag.) was precipitated at rather low fluoride ion concentration ( 0 to $0.1 \mathrm{mM}$ ), and magnesian calcite (Mg-C) was coprecipitated with a small amount of aragonite at 0.5 to $2.5 \mathrm{mM}$ of fluoride ion concentration. Above $3 \mathrm{mM}(57 \mathrm{mg} / \mathrm{l})$ of fluoride ions, monohydrocalcite (MHC) was precipitated. With the increase in fluoride ion concentration in solution, X-ray diffraction angle of (104) spacing of calcite type carbonate in the precipitate varied from $2 \theta\left(\mathrm{CuK}_{\alpha}\right)=29.5$ to $29.7^{\circ}$ continuously. The $\mathrm{Mg} / \mathrm{Ca}$ molar ratio in the carbonate precipitate increased up to 0.1 with increasing fluoride ion concentration in the parent solution up to $2 \mathrm{mM}$. This fact suggests that magnesium carbonate is incorporated as a solid solution into the calcitic calcium carbonate and the presence of fluoride ions in the parent solution enhances the incorporation of magnesium into calcium carbonate lattice as discussed by Ohde and Kitano (1980), whereas magnesium is not incorporated into monohydrocalcite.

The experimental results show that magnesian calcite is successfully synthesized from calcium bicarbonate solutions with $\mathrm{Mg}^{2+}$ ion concentration of around $53.5 \mathrm{mM}(1300 \mathrm{mg} / \mathrm{l})$ and $\mathrm{F}^{-}$ion concentration of 0.5 to $2.5 \mathrm{mM}$ (about 9.5 to $48 \mathrm{mg} / \mathrm{l})$, the $\mathrm{F}^{-} / \mathrm{Mg}^{2+}$ molar ratio ranging from 0.0093 to 0.047 .

It is known that fluoride ions form stable complex ions with magnesium ions. The $\mathrm{MgF}^{+}$ ion pair concentration is so low that the activity of $\mathrm{Mg}^{2+}$ ions does not change significantly owing to the low level of fluoride ions added to the parent solution.

Magnesian calcite was preferencially formed from the solutions with 1 to $2 \mathrm{mM}$ of $\mathrm{F}^{-}$. It is probable that a very small amount of sparringly soluble $\mathrm{CaF}_{2}$ precipitated from the initial solution acts as seeds for magnesian calcite forma- tion. Also, the adsorption of fluoride ions on the surface of carbonate seems to have some important role on the carbonate formation, which will be discussed below.

Effect of inorganic and organic phosphates dissolved in parent solution on crystal form and Mg content of carbonate precipitate

(A) Inorganic phosphate

Effect of inorganic phosphate dissolved in a parent solution on the polymorphic crystalliza-

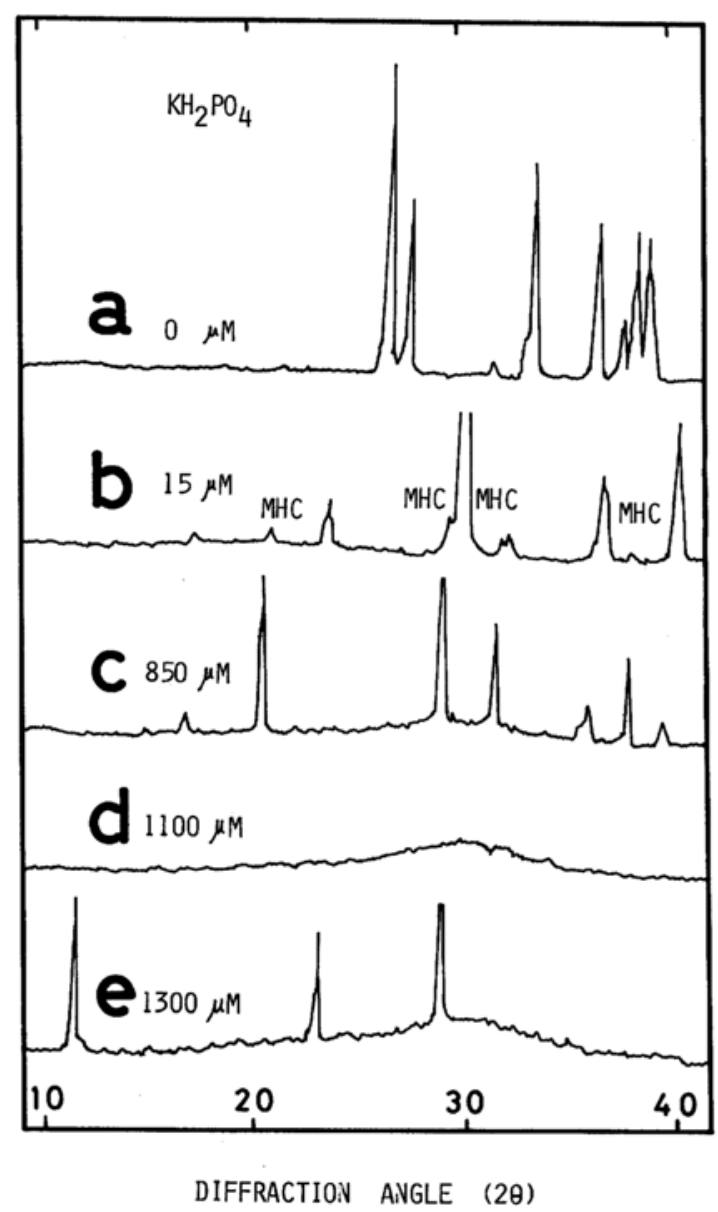

Fig. 2. X-ray diffraction patterns of precipitates formed from solutions containing $\mathrm{MgCl}_{2}(35 \mathrm{mM})$ and $\mathrm{KH}_{2} \mathrm{PO}_{4}\left(0_{-1300 \mu M)}\right.$. 2a: aragonite; $\mathrm{PO}_{4} \mathrm{P}=0 \mu \mathrm{M}$, $2 b$ : magnesian calcite + (monohydrocalcite: $M H C$ in Fig. 2b); $\mathrm{PO}_{4} \mathrm{P}=15 \mu \mathrm{M}, 2 \mathrm{c}$ : monohydrocalcite; $\mathrm{PO}_{4}$ $P=850 \mu M, 2 d$ : amorphous; $P_{4} P=1100 \mu M$ and 2e: $\mathrm{DCPD}\left(\mathrm{CaHPO}_{4} \cdot 2 \mathrm{H}_{2} \mathrm{O}\right) ; \mathrm{PO}_{4} \mathrm{P}=1300 \mu \mathrm{M}$. 
tion of calcium carbonate was studied by adding $\mathrm{KH}_{2} \mathrm{PO}_{4}$ solution to give 0 to $1500 \mu \mathrm{M}$ in the parent solution containing $35 \mathrm{mM}$ and $53.5 \mathrm{mM}$ (850 and $1300 \mathrm{mg} / \mathrm{l}$ ) of $\mathrm{Mg}^{2+}$ ions.

The X-ray diffraction patterns of the formed precipitates at $35 \mathrm{mM}(850 \mathrm{mg} / \mathrm{l})$ of $\mathrm{Mg}^{2+}$ ions are shown in Fig. 2. It is reported that the presence of phosphate ions in a parent solution favors calcite formation but that of $\mathrm{Mg}^{2+}$ aragonite formation. Only aragonite was formed from $\mathrm{Ca}\left(\mathrm{HCO}_{3}\right)_{2}$ solution without phosphate, because of the presence of a large amount of $\mathrm{Mg}^{2+}$ ions in the parent solution. The proportion of magnesian calcite in the precipitates increased with increasing phosphate concentration from 15 to $300 \mu \mathrm{M}$ in the parent solution.

Monohydrocalcite $\left(\mathrm{CaCO}_{3} \cdot \mathrm{H}_{2} \mathrm{O}\right)$ appeared in 500 to $800 \mu \mathrm{M}$ of phosphate in a solution. The magnesium and phosphorous contents of $\mathrm{Mg}$ calcite are $2-3 \mathrm{wt} \%$ and $0.13-3.8 \mathrm{wt} \%$, respectively. And those values of monohydrocalcite are $0.9-2.6 \mathrm{wt} \%$ and $\mathbf{0 . 7}-2.8 \mathrm{wt} \%$, respectively. Above this concentration of phosphate in a parent solution, the relative amount of calcium carbonate precipitates decreased and the amount of calcium phosphate increased. At $1100 \mu \mathrm{M}$ of phosphate in a parent solution, $\mathrm{X}$-ray diffraction patterns of the precipitates show no characteristic peaks. The amorphous precipitate is mainly composed of calcium carbonate containing 2.9 wt $\%$ of $\mathrm{P} . \mathrm{Mg} / \mathrm{Ca}$ molar ratio of the amorphous precipitate was around 0.5 .

The experimental results at $53.5 \mathrm{mM}(1300$ $\mathrm{mg} / \mathrm{l})$ of $\mathrm{Mg}^{2+}$ in the parent solution are shown in Fig. 3. Figure 3 shows the effect of phosphate ions in the parent solution on the mineral composition, the diffraction angle of (104) spacing in calcite type carbonates and the $\mathrm{Mg} / \mathrm{Ca}$ ratio of carbonates formed from the solutions containing various concentration of phosphate in the presence of $53.5 \mathrm{mM}$ of $\mathrm{Mg}^{2+}$ ions. It is apparent that phosphate ions in a parent solution favored magnesian calcite precipitation even the $\mathrm{Mg}^{2+}$ ion concentration is on the same level as that of sea water. Without phosphate ions, only aragonite is formed from sea water inorganically (Kitano and Hood, 1962). Magnesian calcite was

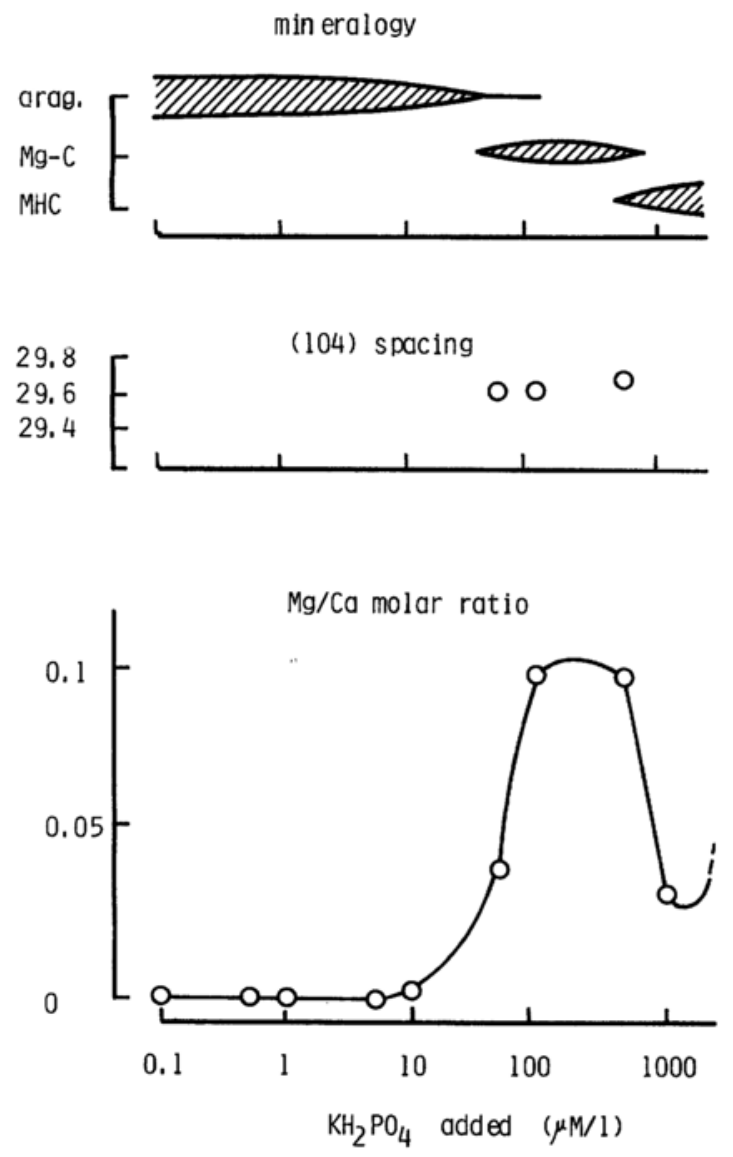

Fig. 3. Effect of $\mathrm{KH}_{2} \mathrm{PO}_{4}$ dissolved in the parent solu-

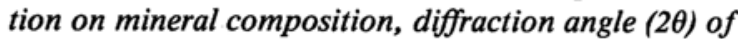
(104) spacing of calcitic carbonates and $\mathrm{Mg} / \mathrm{Ca}$ molar ratio of precipitates. Carbonates are formed from the $10 \mathrm{mM} \mathrm{Ca}\left(\mathrm{HCO}_{3}\right)_{2}$ solution $\left(\mathrm{Ca}^{2+}, 400 \mathrm{mg} / \mathrm{l}\right)$ containing $35 \mathrm{mM} \mathrm{MgCl}(850 \mathrm{mg} / \mathrm{l})$ and $\mathrm{KH}_{2} \mathrm{PO}_{4}(0.1$ to 1500 $\mu M)$.

precipitated with the addition of phosphate ions from 20 to $500 \mu \mathrm{M}$ to the parent solution, with a small amounts of aragonite or monohydrocalcite. The diffraction angle $(2 \theta)$ of (104) spacing of calcite type carbonate is around $29.7^{\circ}$ $\left(\mathrm{CuK}_{\alpha}\right)$. The $\mathrm{Mg} / \mathrm{Ca}$ molar ratio of the formed precipitates increases with increasing phosphate ion concentration in the parent solution up to $100 \mu \mathrm{M}$. Above $500 \mu \mathrm{M} / 1$ of phosphate ions, a small amount of amorphous precipitate appeared on the surface of the solution. X-ray diffraction analysis of the surface floating material showed no characteristic diffraction 
peaks. It would be possible that the formation of amorphous precipitates inhibits magnesian calcite formation but promote the monohydrocalcite formation, though the details are not known well.

(B) Organic phosphate

Phosphorous is one of the most important bio-elements, and a significant amount of phosphorus is contained in marine organisms. In blood or extrapallial fluids of marine organisms, 50 to $500 \mu \mathrm{M}$ of phosphorus are dissolved as both inorganic and organic forms (Simkiss, 1964). It is not known whether or not organic phosphate ions favor the magnesian calcite formation from solutions containing a large amount of $\mathrm{Mg}^{2+}$ ions. In order to verify whether organic phosphate also affects the polymorphic formation of calcium carbonate from aqueous solution, the effect of ATP (adenosine triphosphate disodium salt trihydrate) was examined.

ATP solution was added to give $0,8,25,40$, 100,180 and $370 \mu \mathrm{M}$ in the parent $\mathrm{Ca}\left(\mathrm{HCO}_{3}\right)_{2}$ solution containing $35 \mathrm{mM}$ of $\mathrm{Mg}^{2+}$ ions. ATP is a poly-phosphate which has three $\mathrm{PO}_{4}-\mathrm{P}$ functional groups in the molecular structure. It is found that organic phosphate ions in a parent solution also have a very significant influence on the magnesian calcite formation and the $\mathrm{Mg}$ content of the precipitates as shown in Fig. 4. Magnesian calcites containing around $6 \mathrm{~mol} \%$ of magnesium in the lattice are formed in the presence of 8 to $180 \mu \mathrm{M}$ of ATP in the parent solution. Above this concentration, monohydrocalcite and/or amorphous carbonate (AMC) were formed.

The obtained results suggest that phosphate ions in a parent solution favor the $\mathrm{Mg}$-bearing carbonate formation possibly in biological fluids and probably in interstitial waters of anerobic marine sediments, as well as the dissolved organic materials such as citrate, malete or pyruvate (Kitano and Hood, 1965; Kitano and Kanamori, 1966).

Effects of fluoride and phosphate ions on the interaction between calcite surface and $\mathrm{Mg}^{2+}$ ions
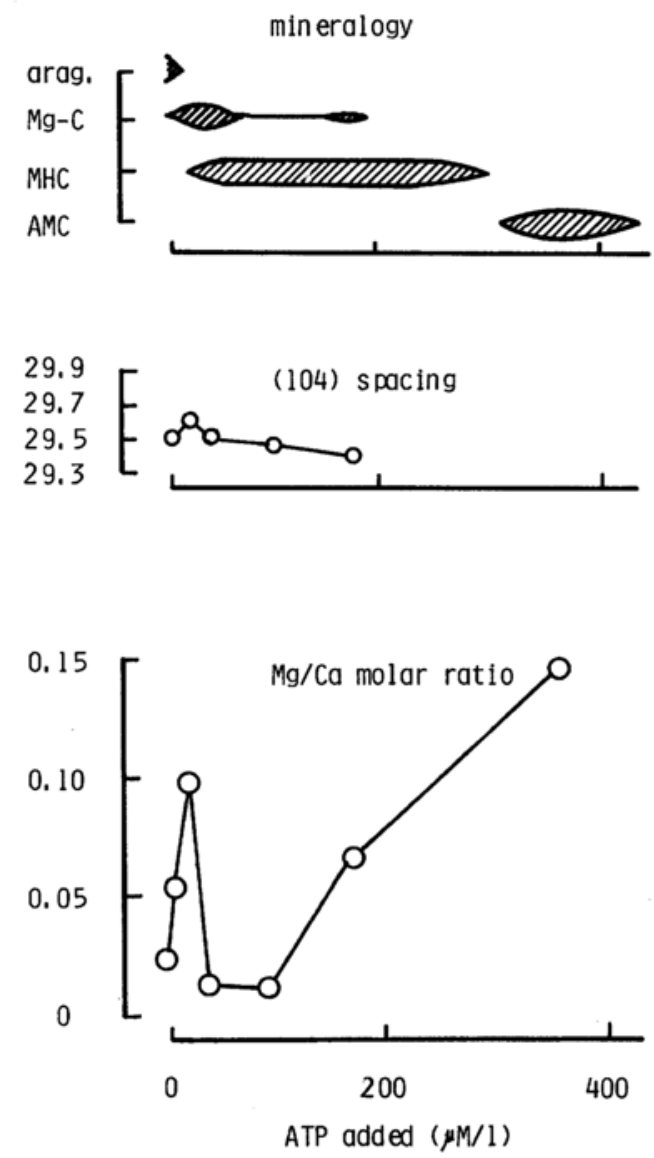

Fig. 4. Effect of ATP (adenosyne-tri-phosphate dosodium salt trihydrate) dissolved in the parent solution on mineral composition, diffraction angle $(2 \theta)$ of (104) spacing of calcitic carbonates and $\mathrm{Mg} / \mathrm{Ca}$ molar ratio of precipitates. Carbonates are formed from the $10 \mathrm{mM} \mathrm{Ca}\left(\mathrm{HCO}_{3}\right)_{2}$ solution $\left(\mathrm{Ca}^{2+}, 400 \mathrm{mg} / \mathrm{l}\right)$ containing $35 \mathrm{mM} \mathrm{MgCl} 2(1300 \mathrm{mg} / \mathrm{l})$ and $\mathrm{ATP}(0$ to $370 \mu \mathrm{M})$.

Clearly fluoride or phosphate ions play an important role in the polymorphic formation of calcium carbonate. For understanding their role in the polymorphic crystallization, the adsorption of $\mathrm{Mg}^{2+}$ ions on calcite surface in the presence of fluoride or phosphate ions in a solution has been examined (the experimental procedure (b)).

The experimental results are shown in Fig. 5. The $\mathrm{Mg}^{2+}$ ion concentration in a solution decreased after the addition of calcite powder owing to the adsorption of $\mathrm{Mg}^{2+}$ ions onto 


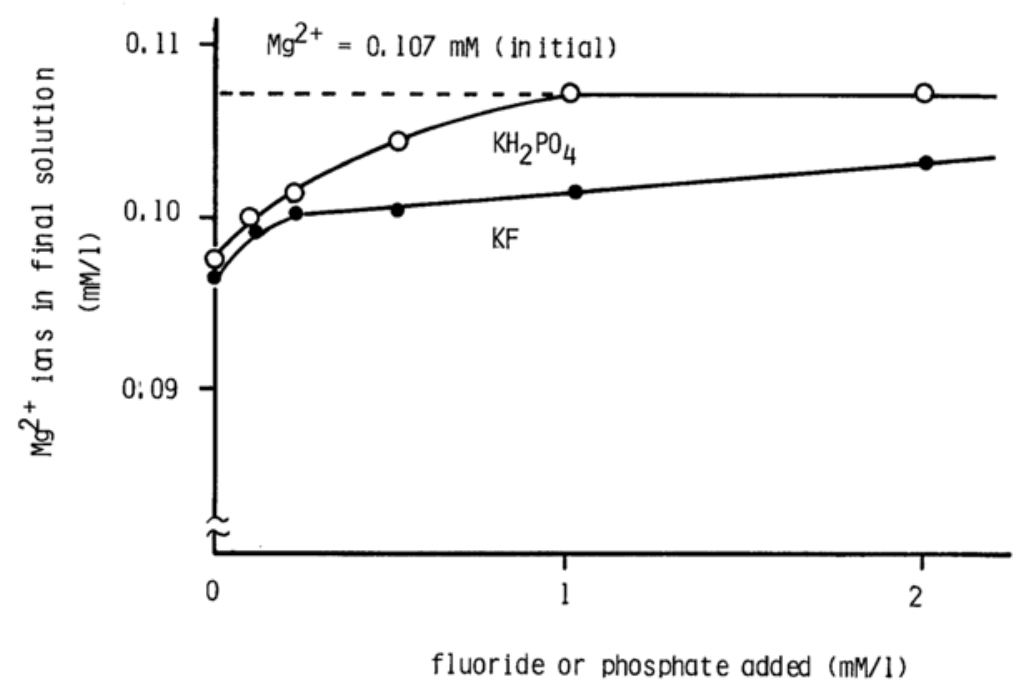

Fig. 5. Effect of fluoride and phosphate ions on the $\mathrm{Mg}^{2+}$ ion adsorption onto calcite surface.

suspended carbonate surface. The amount of magnesium ions remaining in a solution after the addition of carbonate powder increases with the increase in the amount of added fluoride or phosphate ions in a solution. That is, the amount of magnesium ions adsorbed on calcite surface decreases with increasing phosphate or fluoride ion concentration in a solution, and finally it reduces to zero. It is clear that the presence of fluoride or posphate ions in a solution inhibits the adsorption of $\mathrm{Mg}^{2+}$ ions on calcite surface. The required concentration for phosphate ions (1 $\mathrm{mM})$ to inhibit completely the $\mathrm{Mg}^{2+}$ ion adsorption is one-tenth of that of fluoride ions $(10 \mathrm{mM})$. Barium ions $(10 \mathrm{mM})$ and $\mathrm{Ca}^{2+}$ ions (100 mM or more) in a parent solution inhibit $\mathrm{Mg}^{2+}$ ion adsorption on the carbonate surface, and favor the calcitic carbonate formation even in the presence of $\mathrm{Mg}^{2+}$ ions. The sequence of the inhibition effect of ions on the $\mathrm{Mg}^{2+}$ ion adsorption is as follows: phosphate $>\mathrm{Ba}^{2+}, \mathrm{F}^{-}>\mathrm{Ca}^{2+}$. This sequence is consistent with that of the power of ions forming calcitic carbonate from solution containing $\mathrm{Mg}^{2+}$ ions (53.5 mM): phosphate (0.05-0.5 mM) $>$ citrate(0.2 mM, Kitano and Kanamori; 1966), $\mathrm{Ba}^{2+}\left(0.25 \mathrm{mM}\right.$, Kitano et al.; 1979a), $\mathrm{F}^{-}(0.5-$ $2.5 \mathrm{mM})>$ alkalinity(10-50 mM, Oomori et al.; 1983) $>\mathrm{Ca}^{2+}$ (50 mM, Tomiyama and Kitano,
1984).

Magnesium ions form ion pairs such as $\mathrm{MgF}^{+}, \mathrm{MgH}_{2} \mathrm{PO}_{4}^{+}$and $\mathrm{MgHPO}_{4}^{\circ}$ in a solution containing fluoride or phosphate ions. Dearease in the activity of $\mathrm{Mg}^{2+}$ ions owing to the ion pair formation is around $50 \%$ at most, even the sufficient amount of fluoride or phosphate ions for the complete inhibition of the $\mathrm{Mg}^{2+}$ ion adsorption is added.

It is noted that the presence of $\mathrm{Mg}^{2+}$ ions in a solution favors aragonite formation, whereas that of phosphate, fluoride, barium, calcium or citrate ions favors calcite formation. The effects of phosphate ions on the magnesian calcite formation and also on the absorbability of $\mathrm{Mg}^{2+}$ ions onto carbonate surface are especially large. Phosphate or fluoride ions in a solution may change the surface condition of carbonate precipitate and inhibit $\mathrm{Mg}^{2+}$ ion adsorption on the carbonate surface.

Several authors have mentioned the polymorphic crystallization of calcium carbonate. The first concept is based on the thermodynamical consideration (Berner, 1975): Dissolved $\mathbf{M g}^{2+}$ ions in solution, which favor aragonite precipitation from the solution, have a strong retarding effect on the calcite growth, whereas they have no effect on the aragonite growth. This rate inhibition of $\mathrm{Mg}^{2+}$ ions is considered to be due to 
their incorporation in the calcite crystal lattice, which causes the magnesian calcite to be more soluble than pure calcite thermodynamically. Incorporation of foreign ions in crystal lattice may change the stability of calcium carbonate thermodynamically.

The second concept is based on the kinetic aspect (de Kanel and Morse, 1978; Reddy, 1977): Phosphate ions and some other ions have large rate inhibiting effect on the calcium carbonate growth. This is explained as the foreign ions are adsorbed and cover the active site of the carbonate crystal surface. This would also affect the polymorphic formation of calcium carbonate, however the systematic study has not been carried out yet.

The third concept is based on the abnormal incorporation of trace elements into early stages of calcium carbonate precipitation (Kitano et al., 1971; 1980). This is explained as follows: the ions with smaller crystalline ionic radii have larger hydration ionic radii than calcium ions, which favor aragonitic calcium carbonate and easily incorporate into aragonite nucleic calcium carbonate at early stage of crystallization.

It remains unclear whether or not these phenomena have the same relation with the influence of fluoride and phosphate ions on the magnesian calcite formation.

\section{Geochemical implication}

The fluoride ion concentration in sea water ranges from 0.07 to $0.1 \mathrm{mM}(1.3$ to $1.9 \mathrm{mg} / \mathrm{l})$ (Greenhalgh and Riley, 1961; Carpenter, 1969). Hydrothermal waters and interstitial waters show relatively high concentrations of fluoride ions, though the concentrations do not exceed $0.2 \mathrm{mM}$ generally. According to the present experiments, magnesian calcite was formed at fairly high fluoride ion concentrations relative to the concentration in sea water. Therefore, effect of fluoride ions may not be connected directly with the natural calcite formation.

On the other hand, the phosphate concentration of normal sea water is around $2 \mu \mathrm{M}$. A relatively high phosphate ion concentration up to $500 \mu \mathrm{M}$ was observed in interstitial waters of anerobic marine sediments (Scholkovitz, 1973, Gardner, 1973, Gieskes, 1983). The present study suggests that magnesian calcite is possibly formed under such conditions of interstitial waters.

Recently, Baker and Burns (1985) reported protodolomite formation in organic rich marine sediments. Sometimes magnesian calcite and dolomite are observed below the depth of the maximum phosphate ion concentration in interstitial water (Gieskes, 1983). Phosphate ions are expected to act an important role in the formation of magnesian calcite and protodolomite in interstital waters.

It was shown in laboratory synthetic studies that a high carbonate alkalinity solution favored the calcite type carbonate precipitation and the high $\mathrm{Mg}$ content of carbonate (Oomori et al., 1983; Oomori and Kitano, 1987). Such a high carbonate alkalinity solution is observed in the interstitial waters of anerobic marine sediments where sulphate reduction occures. Phosphate ion concentration increases with increasing alkalinity and decreasing sulphate ion concentration through the decomposition of organic materials. It was reported that sulphate ions in a solution inhibit the growth of dolomite (Baker and Kastner, 1981). Sulphate reduction in anaerobic marine sediments by bacterial activity gives rise to increases in carbonate alkalinity and the concentration of dissolved phosphate including both inorganic and organic phosphate, and finally it may bring the formation of $\mathrm{Mg}$ bearing carbonate.

\section{Conclusions}

1) Magnesian calcite was formed from the 10 $\mathrm{mM} \mathrm{Ca}\left(\mathrm{HCO}_{3}\right)_{2}$ solution $\left(\mathrm{Ca}^{2+} ; 400 \mathrm{mg} / \mathrm{l}\right)$ containing both $53.5 \mathrm{mM} \mathrm{Mg}{ }^{2+}$ ions $(1300 \mathrm{mg} / \mathrm{l})$ and 0.5 to $2.5 \mathrm{mM}(9.5$ to $48 \mathrm{mg} / \mathrm{l})$ fluoride ions. 2) Magnesian calcite was formed from the $\mathrm{Ca}\left(\mathrm{HCO}_{3}\right)_{2}$ parent solution containing both 53.5 $\mathrm{mM} \mathrm{Mg}{ }^{2+}$ ions and phosphate ions $(0.05$ to 0.1 $\mathrm{mM} / \mathrm{l})$. These concentrations of phosphate ions are on the same level as observed in the interstitial waters of anerobic marine sediments. 
3) Organic phosphate such as ATP $(8-180 \mu \mathrm{M})$ in a parent solution containing $35 \mathrm{mM}$ of $\mathrm{Mg}^{2+}$ ions also favors the magnesian calcite formation. The role of organic and inorganic phosphate seems to be important for the formation of $\mathrm{Mg}$-bearing carbonate in marine environments.

4) Fluoride or phosphate ions in a parent solution inhibit the adsorption of $\mathrm{Mg}^{2+}$ ions on the calcite surface.

5) The effect of phosphate ions in a solution on the magnesian calcite formation and also on the inhibition of the adsorption of magnesium ions on calcite surface is especially large.

Acknowledgments-The authors are greatful to Emer. Professor K. Kaneshima and Professor H. Taira at University of the Ryukyus for their useful discussions.

\section{REFERENCES}

Baker P. and Burns S. (1985) Occurrence and formation of dolomite in organic-rich continental margin sediments. Amer. Assoc. Petrol. Geol. Bull. 69, 1917-1930.

Baker P. and Kastner M. (1981) Constraints on the formation of sedimentary dolomite. Science 213, 214-216.

Berner R. A. (1975) The role of magnesium in the crystal growth of calcite and aragonite from sea water. Geochim. Cosmochim. Acta 39, 489-504.

Carpenter R. (1969) Factors controlling the marine chemistry of fluoride. Geochim. Cosmochim. Acta 33, 1153-1167.

de Kanel J. and Morse J. W. (1978) The chemistry of ortho-phosphate uptake from sea water onto calcite and aragonite. Geochim. Cosmochim. Acta 42, 1335-1340.

Gardner L. R. (1973) Chemical model for sulphate reduction in closed anaerobic marine environments. Geochim. Cosmochim. Acta 37, 53-68.

Gieskes J. M. (1983) The chemistry of interstitial waters of deep sea sediments: Interpretation of Deep Sea Drilling data. Chemical Oceanography (vol. 8) ed. Riley, J. P. and Chester, R. (Academic Press).

Greenhalgh R. and Riley J. P. (1961) The determination of fluorides in natural waters with particular reference to sea water. Anal. Chim Acta 25, 179188.

Kitano Y. (1962) The behavior of various inorganic ions in the separation of calcium carbonate from a bicarbonate solution. Bull. Chem. Soc. Japan 35, 1973-1980.

Kitano Y. and Hood D. W. (1962) Calcium carbonate crystal forms formed from sea water by inorganic processes. J. Oceanogr. Soc. Japan 18, 141-145.

Kitano Y. and Hood D. W. (1965) The influence of organic materials on the polymorphic crystallization of calcium carbonate. Geochim. Cosmochim. Acta 29, 29-41.

Kitano Y. and Kanamori N. (1966) Synthesis of magnesian calcite at low temperature and pressure. Geochem. J. 1, 1-10.

Kitano Y., Kanamori N. and Tokuyama Y. (1969) Effect of organic matter on solubilities and crystal form of carbonates. Amer. Zoologist 9, 681-688.

Kitano Y., Kanamori N. and Oomori T. (1971) Measurement of distribution coefficients of strontium and barium between carbonate precipitate and solution-Abnormally high value of distribution coefficients measured at early stages of carbonate formation. Geochem J. 4, 183-206.

Kitano Y. and Okumura M. (1973) Coprecipitation of fluoride with calcium carbonate. Geochem. J. 7, 37-49.

Kitano Y., Okumura M. and Idogaki M. (1975) Incorporation of sodium, chloride and sulfate with calcium carbonate. Geochem. J. 9, 75-84.

Kitano Y., Okumura M. and Idogaki M. (1978) Uptake of phosphate ions by calcium carbonate. Geochem. J. 12, 29-37.

Kitano Y., Tokuyama A. and Arakaki T. (1979a) Magnesian calcite synthesis from calcium bicarbonate solution containing magnesium and barium ions. Geochem. J. 13, 181-185.

Kitano Y., Okumura M. and Idogaki M. (1979b) Influence of borate-boron on crystal form of calcium carbonate. Geochem. J. 13, 223-224.

Kitano Y., Okumura M. and Idogaki M. (1979c) Behavior of dissolved silica in parent solution at the formation of calcium carbonate. Geochem. J. 13, 253-260.

Kitano Y., Okumura M. and Idogaki M. (1980) Abnormal behavior of copper (II) and zinc ions in parent solution at the early stage of calcite formation. Geochem. J. 14, 167-175.

Murphy J. and Riley J. P. (1962) A simplified single solution method for the determination of phosphate in natural waters. Anal. Chim. Acta 27, 31-36.

Ohde S. and Kitano Y. (1980) Incorporation of fluoride into $\mathrm{Ca}-\mathrm{Mg}$ carbonates. Geochem. J. 14, 321-324.

Oomori T, Kaneshima K., Taira T. and Kitano Y. (1983) Synthetic studies of protodolomite from 
brine waters. Geochem. J. 17, 147-152.

Oomori T. and Kitano Y. (1985) Catalytic effect of $\mathrm{Mg}^{2+}$ ions on polymorphic crystallization of calcium carbonate. Bull. Coll. Sci. Univ. Ryukyus No. 39, 57-62.

Oomori T. and Kitano Y. (1987) Synthesis of protodolomite from sea water in the presence of dioxane. Geochem. J. 21, 59-65.

Oomori T., Kaneshima H., Maezato Y. and Kitano Y. (1987) Distribution coefficient of $\mathrm{Mg}^{2+}$ ions between calcite and solution at $10-50^{\circ} \mathrm{C}$. Marine Chem. 20, 327-336.
Reddy M. M. (1977) Crystallization of calcium carbonate in the presence of trace concentration of phosphorous-containing anions. J. Cryst. Growth 41, 287-295.

Scholkowicz E. (1973) Interstitial water chemistry of Santa Barbara Basin sediments. Geochim. Cosmochim. Acta 37, 2043-2073.

Simkiss, K. (1964) Phosphate as crystal poisons of calcification. Biol. Rev. 39, 487-505.

Tomiyama, C. and Kitano, Y. (1984) Calcite formation in calcium chloride rich water. Japan J. Limnol. 45, 1-5. 